\title{
AZ MTA-ELTE DIGITÁLIS ÍRÁSTUDÁS ÉS IRODALOMOKTATÁS KUTATÓCSOPORT BEMUTATÁSA
}

\section{INTRODUCING THE RESEARCH GROUP 'DIGITAL LITERACY AND THE TEACHING OF LITERATURE'}

\author{
Molnár Gábor Tamás \\ egyetemi docens, Eötvös Loránd Tudományegyetem Bölcsészettudományi Kar \\ Magyar Irodalom- és Kultúratudományi Intézet, Budapest \\ molnar.gabor.tamas@btk.elte.hu
}

ÖSSZEFOGLALÁS

A beszámoló a kutatócsoport legfőbb tevékenységeit mutatja be. Kitér a kutatásokat vezérlő hipotézisekre, az elmúlt években folytatott iskolai kísérletekre és interjúkra, ismerteti a kutatás eddigi eredményeit és a csoport további kutatási terveit.

\section{ABSTRACT}

This report summarizes the most important activities of the research group. It recaps the guiding hypotheses, references the classroom experiments, and the interviews conducted, sums up the results of the research, and previews further plans of the group.

Kulcsszavak: digitális írástudás, szövegértés és -feldolgozás, digitális annotáció, multimédiás feldolgozás, szakmai identitás

Keywords: digital literacy, text comprehension, digital annotation, multimedia adaptation, professional identity

Kutatócsoportunk (URL1) 2016-os megalakulása óta részint digitális bölcsészeti fejlesztéseket, részint szakmódszertani/tanulástudományi kutatásokat és fejlesztéseket végzett. Csoportunkat kizárólag az MTA Szakmódszertani Programja támogatja, nem korábban megkezdett fejlesztéseket és kutatásokat folytatunk. A kutatásainkat kezdettől az alábbi hipotézisek vezérelték: 1) a digitális átalakulás az irodalomtanítást a többi tantárgynál is mélyebben érinti, amennyiben 
az olvasási kultúra mély változását hozza magával, amely a szakmai identitás újradefiniálását teszi szükségessé; 2) a tanítási kultúra sikeres adaptálásához elengedhetetlen a közoktatás és a tanárképzés párhuzamos, együttes átalakítása. (A digitális irodalomoktatás elméletét és részterületeit jól tekinti át Simone Giusti [2015], a bölcsész- és tanárképzés digitális átalakulásáról lásd L. Varga Péter és szerzőtársai könyvét [2018].)

Kutatási tevékenységeink közül a három éven keresztül folytatott iskolai kísérleteket és a harmadik évben megkezdett tanári félig strukturált interjúsorozatot emelném ki, amelyek fenti hipotéziseinket jórészt megerősítették. Fontos eredmény továbbá, hogy az iskolai kísérletek eredményeit hasznosító tanártovábbképzésünket a harmadik év végére sikerült akkreditáltatnunk, ennek kezdeti népszerűsége kiugró: a meghirdetéstől számított néhány napon belül három turnus telt meg. Az első turnust vegyes módszertannal (élő és online modulok együttese) tartottuk meg. A továbbképzést részint további adatgyüjtésre is használjuk, így több iskola, köztük számos vidéki intézmény tanárait és tanulóit is bevonhatjuk a kutatásba. A válsághelyzet különös hangsúlyt ad kutatásainknak, hiszen a teljes tanártársadalom kénytelen élni a digitalizáció kínálta lehetőségekkel.

Az iskolai kísérletek 2017 tavaszán kezdődtek, és részben változó közremüködőkkel azóta is folytatódnak. Jelenleg öt középiskola hat tanára dolgozik aktívan a kísérletek megvalósításán. A kísérletek első nagyobb blokkjában a szövegfeldolgozás módszereit teszteltük digitális környezetben: elöször a digitális annotációt, majd a kreatív-produktív, végül a multimédiás szövegfeldolgozást. Kutatási kérdéseink egyebek között arra irányultak, hogy a digitális környezetben történő szövegfeldolgozás miként befolyásolja a diákok együttmüködési képességét, valamint tantárgyi attitüdjét (ehhez előzményként lásd Tim Hetland kötetének [2017] számos fejezetét). A tanári interjúk, a szöveges és számokban is kifejezhető tanulói válaszok alapján igazolódott az a feltételezés, hogy a megfelelően használt digitális annotációs szoftverek erősíthetik a szövegértelmezés közösségi jellegét, ezzel interaktív módon biztosíthatnak hozzáférést irodalmi szövegekhez és hagyományokhoz (Gonda-Molnár, 2018). A digitális közegben a tanulók többsége bátran hozzászólt a feldolgozott szövegekhez, és a többiek munkáját is láthatta. A multimédiás szövegfeldolgozás vizsgálata pedig azt az eredményt hozta, hogy az irodalmi alkotások más médiumokba történő áthelyezése jó eszköz lehet az irodalom müvészeti oldalának megtapasztaltatására (Gonda-Molnár, 2019). A kísérletek során létrejött tematikus tervek, tananyagok egyik nem várt, de logikus vonása az, hogy a tanárok túlnyomó része rövid, jól áttekinthető méretü szövegekkel (versekkel, novellákkal) dolgozik; a regények és a drámák háttérbe szorulnak. Ez részint betudható a módszertani innováció szükségszerü következményének. Azonban a huszonegy tapasztalt magyartanárral elkészített interjúink egyik első tanulsága is ez: a középiskolai magyartanárok a néhány évtizeddel ezelőtti visszajelzésekhez képest (lásd Győri, 2004) jóval kisebb mértékben tudnak 
terjedelmes szövegeket feldolgoztatni, így a módszertani kísérletezés a kisebb terjedelmű szövegeken vagy szövegrészleteken folytatódik. Ez a fordulat egyrészt a befogadók igényeihez, képességeihez és kultúrafogyasztási szokásaihoz való módszertani alkalmazkodás szükségét jelzi, másrészt lehetővé teszi a „,szoros olvasás" Magyarországon korábban kevésbé elterjedt módszertanának erősödését. Ez a fordulat egyszersmind a fogalom átértelmezését is magával hozhatja: immár nemcsak szövegeket, hanem egyéb médiumokat is meg kell tanulnunk szorosan, a hatásmechanizmusokra gondosan figyelve olvasni. Eredményeink ezen a ponton összekapcsolódnak a nemzetközi kutatások tanulságaival. (A „szoros olvasás” módszertani előzményeihez és digitális vonatkozásaihoz lásd Adam Hammond mủvét [2016], a kutatási eredményeinket Gonda Zsuzsa és Molnár Gábor Tamás [2019] foglalja össze.)

Az iskolai kísérletek harmadik évében tanáraink a Szívlapát címü kortárs költészeti antológia (URL2) digitális feldolgozására vállalkoztak. Ennek a vállalkozásnak a legnagyobb nyeresége az, hogy az antológia tematikus elrendezésének köszönhetően a kortárs szövegek jól összekapcsolhatók a tantervileg elöírt irodalomtörténeti anyaggal. Miközben arra nem találtunk bizonyítékot, hogy a kortárs irodalom digitális feldolgozása növelné a tanulók olvasási kedvét, a digitális eszközök és technikák pozitívan befolyásolták a diákok tantárgyi attitüdjét. Vagyis elsősorban nem az irodalom, hanem az irodalomóra élvezeti értékét növelték. Csak további, hosszú távú vizsgálódással válaszolható meg az a kérdés, hogy van-e konkrét összefüggés az irodalomórai tevékenységek öröme és az irodalomolvasás élvezete között.

A kutatócsoportunkhoz kapcsolódó digitális bölcsészeti fejlesztések között említendő két alapozó kurzus digitális változatának kidolgozása, egy digitális bölcsészeti Wiki folyamatos fejlesztése, valamint a csoportunkkal szorosan együttműködő Eötvös Loránd Tudományegyetem Digitális Bölcsészeti Központ jóvoltából a Bölcsészettudományi Kar összes alapszakos és doktori hallgatójának kötelező digitális bölcsészeti és összes oktatójára kiterjedő digitális módszertani képzés elindítása. A digitális bölcsészethez kapcsolódóan kutatócsoportunk két nemzetközi konferencia budapesti megrendezéséhez is hozzájárult, valamint a digitális archívumok kezelésével kapcsolatos nemzetközi publikációk is születtek (vö. Palkó, 2019; Ries-Palkó, 2019).

Amennyiben csoportunk további támogatásban is részesül, elsősorban a már megkezdett kutatások kiterjesztésén, elmélyítésén dolgoznánk tovább. Így a tanári mélyinterjúkból kiolvasott föbb kérdésirányok mentén nagymintás kérdőíves kutatást végeznénk a magyartanárok irodalomfogalmairól, valamint ezeknek a digitális átalakulással való összeegyeztethetőségéről. A tanulói attitüdökkel kapcsolatos eredmények nyomán kidolgoznánk egy hosszanti kutatást, amely a digitális irodalomórai (és otthoni tanulási) tevékenységeknek az olvasási motivációra és olvasási képességekre tett hatását mérné. 


\section{IRODALOM}

Giusti, S. (2015): Didattica della letteratura 2.0. Roma: Carocci Editore

Gonda Zs. - Molnár G. T. (2018): Digitális annotáció az irodalomtanításban. Iskolakultúra, 5-6, 113-127. http://www.iskolakultura.hu/index.php/iskolakultura/article/view/31589/31275

Gonda Zs. - Molnár G. T. (2019): Irodalomértés és kreatív szövegfeldolgozás a digitális magyarórán. Iskolakultúra, 4-5, 33-49. http://www.iskolakultura.hu/index.php/iskolakultura/article/ download/32003/31512/

Győri J. (2004): A magyartanitás mestersége. Mestertanárok a magyartanitásról. Budapest: Krónika Nova Kiadó

Hammond, A. (2016): Literature in the Digital Age. An Introduction. Cambridge University Press DOI: $10.1017 / \mathrm{CBO} 9781107323551$

Hetland, T. (ed.) (2017): Teaching Literature with Digital Technology. Assignments. New York: MacMillan

L. Varga P. - Molnár G. T. - Palkó G. (szerk.) (2018): Digitális szövegkultúrák a bölcsészképzésben. Budapest: ELTE BTK

Palkó G. (2019): Sites of Digital Humanities: About Virtual Research Environments. In: Kelemen P. - Pethes, N. (eds.): Philology in the Making: Analog/digital Cultures of Scholarly Writing and Reading. Bielefeld: Transcript Verlag

Ries, T. - Palkó G. (2019): Born Digital Archives. International Journal of Digital Humanities, 1-11. https://link.springer.com/article/10.1007/s42803-019-00011-x

URL1: www.diio.hu

URL2: szivlapatprojekt.wordpress.com 